19 Revue d'histoire du XIXe siècle

Société d'histoire de la révolution de 1848 et des

révolutions du XIXe siècle

13 | 1996

(Re)penser le XIXe siècle

\title{
De l'artiste paranoïaque et révolutionnaire à l'artiste révolté et schizophrène
}

\section{Frédéric Gros}

\section{OpenEdition \\ Journals}

Electronic version

URL: http://journals.openedition.org/rh19/101

DOI: $10.4000 /$ rh19.101

ISSN: 1777-5329

\section{Publisher}

La Société de 1848

\section{Printed version}

Date of publication: 1 December 1996

ISSN: 1265-1354

\section{Electronic reference}

Frédéric Gros, «De l'artiste paranoïaque et révolutionnaire à l'artiste révolté et schizophrène », Revue d'histoire du XIXe siècle [Online], 13 | 1996, Online since 10 September 2008, connection on 03 May 2019. URL : http://journals.openedition.org/rh19/101 ; DOI : 10.4000/rh19.101

This text was automatically generated on 3 May 2019.

Tous droits réservés 


\title{
De l'artiste paranoïaque et révolutionnaire à l'artiste révolté et schizophrène
}

\author{
Frédéric Gros
}

\section{ABSTRACTS}

No abstract available by now

Pas de résumé disponible actuellement

INDEX

Mots-clés: Penser le dix-neuvième siècle, Arts 